\section{OPEN ACCESS}

E-ISSN : 2549-6581

Artikel Hasil Penelitian

Diterima : 06 Desember 2017

Direview : 09 Januari 2018

Dimuat : Desember 2017 - Maret 2018
Journal of Issues in Midwifery

\title{
Analisis Perilaku Kesehatan Dan Faktor Resiko Kejadian Preeklampsia Pada Ibu Hamil Di Poliklinik Obstetri Gynekologi RSUD Kabupaten Kediri
}

\author{
Fitri Yuniarti ${ }^{\left.{ }^{*}\right)}$, Wahyu Wijayati ${ }^{1}$, Dintya Ivantarina ${ }^{1}$ \\ 1. Program Studi D3 Kebidanan, STIKES Karya Husada Kediri \\ *)Email : fitri.mkk@gmail.com \\ TIp : 08563693610
}

\begin{abstract}
Preeclampsia is associated with significant pathological changes in maternal and fetal blood vessels and placenta. The purpose of this study is to determine the health behavior and risk factors that affect the incidence of preeclampsia in pregnant women in Obstetric Gynecology Polyclinic of Kediri Regency Hospital. The study design used is descriptive analytic with cross sectional approach. This study was conducted in June-August 2017 in Obstetric Gynecology Polyclinic of Kediri Regency Hospital. The population in this study were all mothers who came to check their pregnancy in Obstetric Gynecology Polyclinic of Kediri Regency Hospital with the number of samples obtained was 181 pregnant women in random sampling. Data were analyzed in univariate, bivariate with chi square and multivariate test with multiple logistic regression test. The result of study showed that there was a correlation between weight gain $(p=0.005)$ and medical history $(p=0.022)$ to incidence of preeclampsia while education level, family income, service range, transportation, nutritional status, ANC examination, KIA book ownership, mother age, parity, family history of preeclampsia, obesity, twin pregnancy, gestational interval and gestational diabetes, there is an insignificant relationship. The result of multivariate analysis showed that the weight gain $(p=0.007)$ and medical history $(p=0.029)$ had a significant association with the incidence of preeclampsia in pregnant women. Health behaviors and risk factors that affect the incidence of preeclampsia in pregnant women is the increase in maternal weight during pregnancy and medical history suffered by the mother before pregnancy.
\end{abstract}

Keywords: Health Behavior, Risk Factors, Preeclampsia 


\begin{abstract}
ABSTRAK
Preeklampsia berhubungan dengan perubahan patologis yang signifikan dari pembuluh darah ibu dan janin serta plasenta. Tujuan penelitian ini untuk mengetahui perilaku kesehatan dan faktor-faktor resiko yang mempengaruhi kejadian preeklampsia pada ibu hamil di Poliklinik Obstetri Gynekologi RSUD Kabupaten Kediri. Desain penelitian yang digunakan yaitu deskriptif analitik dengan pendekatan cross sectional. Penelitian ini dilakukan pada bulan Juni-Agustus 2017 di Poliklinik Obstetri Gynekologi RSUD Kabupaten Kediri. Populasi dalam penelitian ini adalah semua ibu yang datang memeriksakan kehamilannya di Poliklinik Obstetri Gynekologi RSUD Kabupaten Kediri dengan jumlah sampel yang didapat yaitu 181 ibu hamil secara random sampling. Data dianalisis secara univariate, bivariate dengan uji chi kuadrat dan multivariate dengan uji regresi logistik berganda. Hasil penelitian menunjukkan ada hubungan kenaikan berat badan $(p=0,005)$ dan riwayat medis $(p=0,022)$ terhadap kejadian preeklampsia sedangkan pendidikan, pendapatan keluarga, jangkauan pelayanan, transportasi, status gizi, pemeriksaan ANC, kepemilikan buku KIA, usia ibu, paritas, riwayat keluarga preeklampsia, obesitas, kehamilan kembar, interval kehamilan dan diabetes gestasional terdapat hubungan yang tidak signifikan. Hasil analisis multivariat menunjukkan faktor paling dominan terhadap kejadian preeklampsia adalah kenaikan berat badan $(p=0,007)$. Kenaikan berat badan $(p=0,007)$ dan riwayat medis $(p=0,029)$ mempunyai hubungan yang bermakna dengan kejadian preeklampsia pada ibu hamil dan berperan sebagai prediktor untuk kejadian preeklampsia dengan kuat prediksi sebesar $18 \%\left(R^{2}=0,180\right)$. Perilaku kesehatan dan faktor resiko yang mempengaruhi terhadap kejadian preeklampsia pada ibu hamil yaitu kenaikan berat badan ibu selama hamil dan riwayat medis yang diderita oleh ibu sebelum hamil.
\end{abstract}

Kata kunci: Kebutuhan, Pendidikan Seksualitas, Sekolah Dasar 


\section{PENDAHULUAN}

Status kesehatan maternal merupakan salah satu indikator untuk melihat derajat kesehatan perempuan. Angka kesakitan dan kematian ibu merupakan indikator yang penting dalam menggambarkan status kesehatan maternal. Kesehatan ibu dan Anak (KIA) merupakan salah satu target yang ditentukan dalam tujuan AGENDA $2030 \quad$ (Sustainable Development Goals) yang ke-3 yaitu menargetkan AKI (Angka Kematian Ibu) 70 per 100.000 kelahiran hidup, AKB (Angka Kematian Bayi) maksimum 12 per 1000 kelahiran hidup dan angka kematian balita maksimum 25 per 1000 kelahiran hidup ${ }^{1}$. Kesehatan ibu dan Anak (KIA) merupakan salah satu target yang ditentukan dalam SDGs 2030 namun angka kematian ibu, bayi dan balita di Indonesia masih tergolong tinggi dan merupakan salah satu masalah utama kesehatan.

Data Dinkes Propinsi Jawa Timur Tahun 2015 AKI berjumlah 121, penyebab langsung AKI yaitu perdarahan 21,81\%, eklampsia/ preeklampsia 36,29\%, jantung $12,93 \%$, infeksi 22,90\% dan penyebab lain $6,07 \%$. Sedangkan AKB di Propinsi Jawa Timur Tahun 2015 sebesar 154 kematian bayi ${ }^{2}$. Angka kematian ibu (AKI) di Kabupaten Kediri Tahun 2016 sejumlah 16 jiwa atau 65,73 per 100.000 kelahiran hidup. Penyebab kematian ibu di Kabupaten Kediri antara lain perdarahan sebesar 7 jiwa $(43,75 \%)$, preeklampsia sebesar 6 jiwa $(37,5 \%)$, penyakit lainnya 3 jiwa (18,75\%). Angka kematian bayi di Kabupaten Kediri Tahun 2016 sebanyak 142 kematian bayi. Adapun penyebab AKB adalah gangguan atau kelainan pernapasan (asfiksia) $44(30,98 \%)$, prematuritas atau BBLR $60(42,25 \%)$, infeksi 8 $(5,63 \%)$, kelainan bawaan 19 $(13,38 \%)$ dan gangguan lainnya 11 $(7,74 \%) .{ }^{3}$ RSUD Kabupaten Kediri merupakan rumah sakit rujukan terbesar di tingkat Kabupaten Kediri. Menurut data yang didapatkan dari Rekam Medis RSUD Kabupaten Kediri pada Tahun 2015 penderita preeklampsia yang dirawat di instalasi rawat inap obstetri dan poliklinik obstetri gynekologi sebanyak 124 ibu hamil ${ }^{5}$.

Salah satu penyebab AKI dan penyebab tidak langsung dari AKB adalah preeklampsia. Preeklampsia adalah sindrom hipertensi kehamilan tertentu dengan kondisi multisistem dengan multifaktorial penyebab, unik untuk manusia, yang berhubungan secara signifikan terhadap angka kematian dan kesakitan maternal dan perinatal ${ }^{6,7}$. Kondisi yang kompleks ini berhubungan dengan perubahan patologis yang signifikan dari pembuluh darah ibu dan janin serta plasenta, termasuk arteriolopathy desidua, infark, perubahan iskemik dan abruption, oleh karena itu tidak mengherankan bahwa hasil perinatal dipengaruhi oleh sindrom ini, khususnya dalam konteks penyakit berat. Penyebab preeklamsia lainnya umumnya terkait dengan lesi plasenta. Manifestasi vaskular yang mendasari, dan adanya stres oksidatif dan kerusakan endotel, mempengaruhi sirkulasi uteroplasenta dan dapat menyebabkan hambatan pertumbuhan janin dengan hipoksia yang mendasari dan asidosis yang bisa menyebabkan terjadinya IUFD ${ }^{8,9}$. Pada bayi akan menyebabkan kelahiran 
prematuritas yang memberikan dampak terjadinya asfiksia, berat badan lahir rendah, serta komplikasikomplikasi lain yang berakibat kematian sedangkan pada ibu preeklampsia dapat menyebabkan terjadinya eklampsia (kejang kehamilan) yang berujung pada kematian $^{6}$.

Upaya yang dapat dilakukan untuk menurunkan angka kesakitan dan kematian ibu dan bayi yaitu melakukan deteksi dini tanda dan bahaya dalam kehamilan. Melalui tanda-tanda klinis pada saat perawatan antenatal dengan pemantauan kenaikan tekanan darah, proteinuria, kenaikan berat badan selama hamil dan status gizi serta menghindari faktor-faktor yang beresiko untuk terjadinya preeklampsia dalam kehamilan. Pedoman terbaru dari the National Institute for Health and Clinical Excellence (NICE) merekomendasikan skrining rutin faktor risiko spesifik untuk preeklampsia (nulliparity, usia yang lebih tua, indeks massa tubuh, riwayat keluarga preeklampsia, riwayat penyakit ginjal atau hipertensi kronis, kehamilan ganda, interval kehamilan lebih dari 10 tahun, dan riwayat preeklampsia pada kehamilan sebelumnya) ${ }^{9}$. Adanya skrining rutin faktor resiko spesifik untuk preeklampsia dan pemantauan perilaku kesehatan yang baik, diharapkan para ibu bisa melakukan pemeriksaan kehamilan secara rutin ke tenaga kesehatan dan jika dideteksi adanya tanda bahaya atau komplikasi yang menyertai kehamilan maka petugas kesehatan bisa melakukan deteksi dini kegawatdaruratan maternal dan neonatal, melakukan pemantauan secara intensif kesejahteraan ibu dan janin, melakukan rujukan dini terencana apabila dibutuhkan sehingga mengurangi komplikasi ke ibu dan janin ${ }^{10}$.

Berdasarkan latar belakang yang telah diuraikan di atas peneliti tertarik untuk meneliti lebih lanjut perilaku kesehatan meliputi pendidikan, pendapatan keluarga, jangkauan pelayanan, transportasi, status gizi, kenaikan berat badan, pemeriksaan ANC, kepemilikan buku KIA dan faktor-faktor yang mempengaruhi kejadian preeklampsia meliputi usia ibu, paritas, riwayat keluarga, obesitas, kehamilan kembar, interval kehamilan, diabetes gestasional dan riwayat medis pada ibu hamil di Poliklinik Obstetri Gynekologi RSUD Kabupaten Kediri.

Tujuan penelitian ini untuk mengetahui gambaran tentang kejadian preeklampsia pada ibu hamil serta perilaku kesehatan dan faktor-faktor resiko yang mempengaruhi preeklampsia di Poliklinik Obstetri Gynekologi RSUD Kabupaten Kediri.

\section{METODE PENELITIAN}

Desain penelitian yang digunakan adalah deskriptif analitik. Adapun populasi dalam penelitian ini adalah semua ibu yang datang memeriksakan kehamilannya di Poliklinik Obstetri Gynekologi di RSUD Kabupaten Kediri. Teknik sampling yang digunakan yaitu random sampling. Sampel yang digunakan adalah ibu yang datang memeriksakan kehamilannya di Poliklinik Obstetri Gynekologi di RSUD Kabupaten Kediri yang memenuhi kriteria inklusi sejumlah 181 ibu hamil. Variabel dalam penelitian ini terdiri dari variabel independen yaitu perilaku kesehatan 
dan faktor resiko preeklampsia, variabel dependen yaitu kejadian preeklampsia pada ibu hamil. Pengumpulan data menggunakan data primer berupa lembar kuesioner dengan teknik wawancara terstruktur dan observasi dan data sekunder berupa rekam medik ibu hamil yang memeriksakan kehamilan di poli obstetri gynekologi RSUD Kabupaten Kediri. Penelitian ini dilakukan pada bulan Juni-Agustus 2017 di Poliklinik Obstetri Gynekologi RSUD Kabupaten Kediri dengan sebelumnya dinyatakan laik etik oleh Komisi Etik Lembaga Penelitian dan Pengabdian Masyarakat STIKES Karya Husada Kediri. Kemudian data diolah dan dianalisis secara univariate, bivariate dengan uji statistik chi kuadrat $\left(x^{2}\right)$ derajat kepercayaan 95\% dan tingkat kemaknaan (alpha) 0,05 dan multivariate dengan uji statistik regresi logistik berganda.

\section{HASIL PENELITIAN}

Pada tabel 1 berdasarkan distribusi frekuensi perilaku kesehatan pada ibu hamil di poliklinik obstetri gynekologi RSUD Kabupaten Kediri dapat diketahui bahwa sebagian besar responden memiliki tingkat pendidikan SD/SMP $(56,4 \%)$, pendapatan keluarga $>\mathrm{Rp}$ $1.456 .000 \quad(57,5 \%)$, jangkauan pelayanan kesehatan dengan jarak tempuh >2 km (93,3\%), kendaraan yang digunakan menuju tempat pemeriksaan kehamilan dengan motor/mobil pribadi $(94,5 \%)$, status gizi ibu dengan kondisi lila $>23,5 \mathrm{~cm}$ $(81,2 \%)$, kenaikan berat badan $<11,5$ $\mathrm{kg} \quad(81,2 \%)$, jumlah kunjungan pemeriksaan ANC $>4 \times(76,8 \%)$ dan memiliki buku KIA yang pernah dibaca untuk mengetahui isi dan kegunaan buku tersebut $(98,9 \%)$.

Tabel 1. Distribusi Frekuensi Perilaku Kesehatan Pada Ibu Hamil di Poliklinik Obstetri Gynekologi RSUD Kabupaten Kediri Bulan Juni-Agustus 2017

\begin{tabular}{|c|c|c|}
\hline Variabel & $f(n=181)$ & $\%$ \\
\hline \multicolumn{3}{|l|}{ Pendidikan } \\
\hline SD/SMP & 102 & 56,4 \\
\hline SMA & 62 & 34,2 \\
\hline PT & 17 & 9,4 \\
\hline \multicolumn{3}{|l|}{ Pendapatan Keluarga } \\
\hline$<\operatorname{Rp} 1.456 .000$ & 77 & 42,5 \\
\hline$>\operatorname{Rp} 1.456 .000$ & 104 & 57,5 \\
\hline \multicolumn{3}{|l|}{ Jangkauan Pelayanan } \\
\hline$<1 \mathrm{~km}$ & 1 & 0,6 \\
\hline$\geq 1 \mathrm{~km}$ & 11 & 6,1 \\
\hline$>2 \mathrm{~km}$ & 169 & 93,3 \\
\hline \multicolumn{3}{|l|}{ Transportasi } \\
\hline Jalan Kaki & 1 & 0,6 \\
\hline Angkot & 9 & 4,9 \\
\hline Motor/Mobil Pribadi & 171 & 94,5 \\
\hline \multicolumn{3}{|l|}{ Status Gizi Ibu } \\
\hline Lila $<23,5 \mathrm{~cm}$ & 29 & 16 \\
\hline Lila $23,5 \mathrm{~cm}$ & 5 & 2,8 \\
\hline Lila $>23,5 \mathrm{~cm}$ & 147 & 81,2 \\
\hline \multicolumn{3}{|l|}{ Kenaikan Berat Badan } \\
\hline$<11,5 \mathrm{~kg}$ & 147 & 81,2 \\
\hline
\end{tabular}




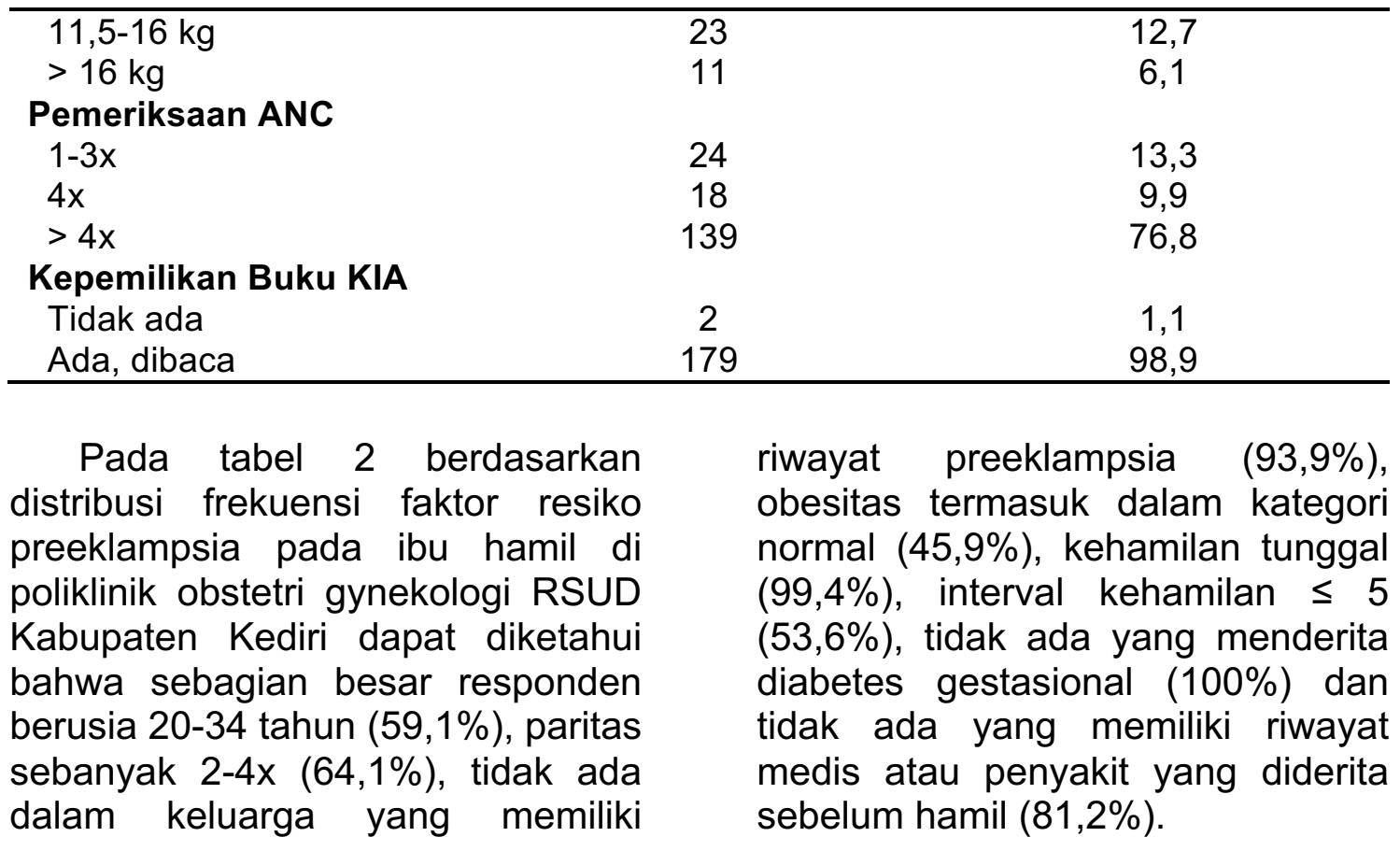

Tabel 2. Distribusi Frekuensi Faktor Resiko Preeklampsia Pada Ibu Hamil di Poliklinik Obstetri Gynekologi RSUD Kabupaten Kediri Bulan Juni-Agustus 2017

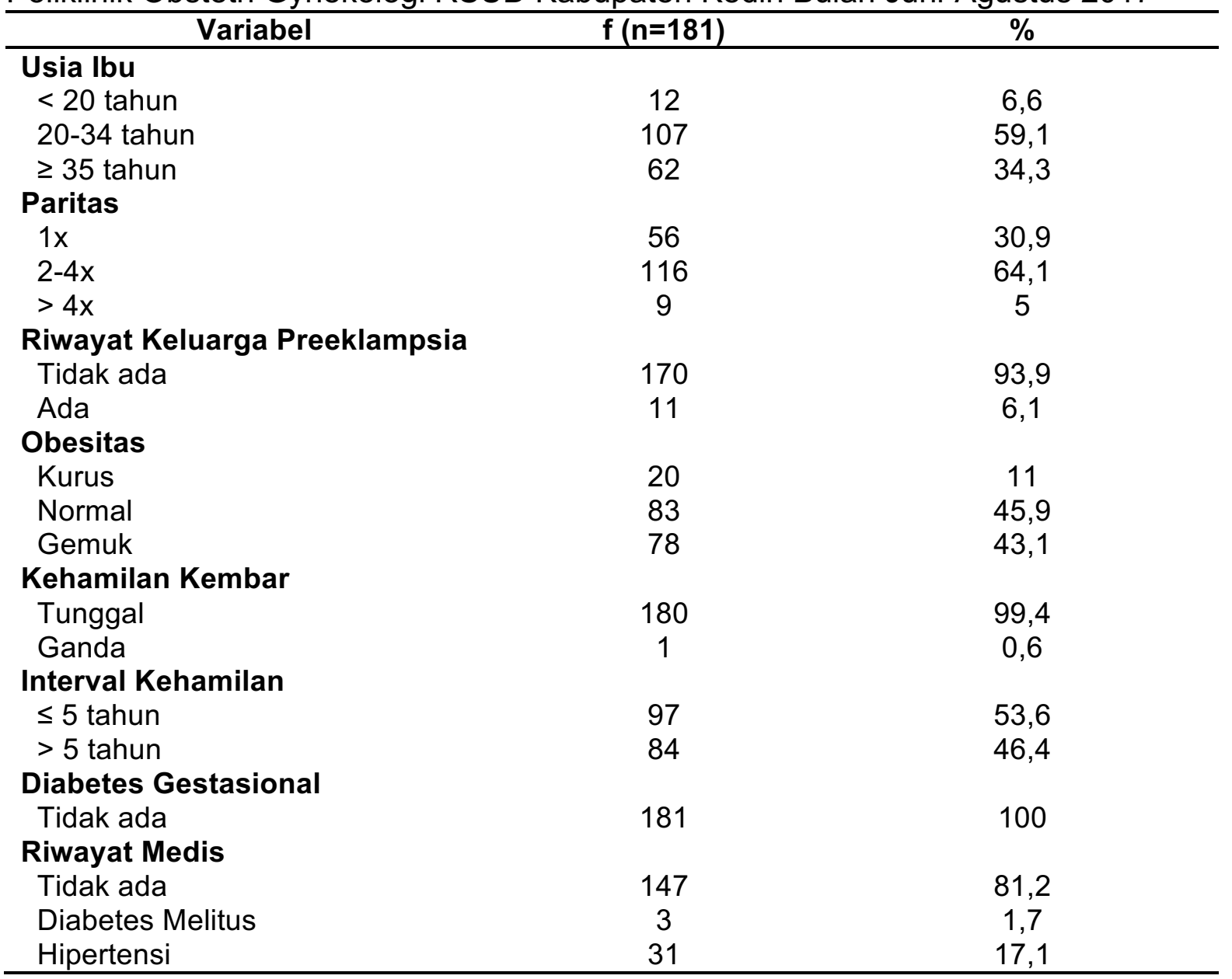


Pada tabel 3 berdasarkan distribusi frekuensi kejadian preeklampsia pada ibu hamil di Poliklinik Obstetri Gynekologi RSUD Kabupaten Kediri menunjukkan bahwa ibu hamil yang mengalami preeklampsia sejumlah $18,8 \%$ dan yang tidak mengalami preeklampsia sejumlah $81,2 \%$.

Tabel 3. Distribusi Frekuensi Kejadian Preeklampsia Pada Ibu Hamil di Poliklinik Obstetri Gynekologi RSUD Kabupaten Kediri Bulan Juni-Agustus 2017

\begin{tabular}{lcc}
\multicolumn{1}{c}{ Variabel } & $\mathbf{f}(\mathbf{n}=\mathbf{1 8 1})$ & $\%$ \\
\hline Preeklampsia & & \\
Ya & 34 & 18,8 \\
Tidak & 147 & 81,2 \\
\hline
\end{tabular}

Tabel 4. Hubungan Perilaku Kesehatan terhadap Kejadian Preeklampsia Pada Ibu Hamil di Poliklinik Obstetri Gynekologi RSUD Kabupaten Kediri Bulan JuniAgustus 2017

\begin{tabular}{|c|c|c|c|c|c|c|c|}
\hline \multirow{3}{*}{ Variabel } & \multicolumn{6}{|c|}{ Preeklampsia } & \multirow{3}{*}{$\boldsymbol{P}$} \\
\hline & \multicolumn{2}{|c|}{$\mathrm{Ya}$} & \multicolumn{2}{|c|}{ Tidak } & \multicolumn{2}{|c|}{ Total } & \\
\hline & $n$ & $\%$ & $\mathbf{N}$ & $\%$ & $\mathbf{n}$ & $\%$ & \\
\hline \multicolumn{8}{|l|}{ Pendapatan Keluarga } \\
\hline$<\operatorname{Rp} 1.456 .000$ & 17 & 9,4 & 60 & 33,1 & 77 & 42,5 & \multirow[t]{2}{*}{0,329} \\
\hline$>\operatorname{Rp} 1.456 .000$ & 17 & 9,4 & 87 & 48,1 & 104 & 57,5 & \\
\hline \multicolumn{8}{|l|}{ Jangkauan Pelayanan } \\
\hline$<1 \mathrm{~km}$ & 0 & 0 & 1 & 0,6 & 1 & 0,6 & \multirow[t]{3}{*}{0,276} \\
\hline$\geq 1 \mathrm{~km}$ & 4 & 2,2 & 7 & 3,9 & 11 & 6,1 & \\
\hline$>2 \mathrm{~km}$ & 30 & 16,6 & 139 & 76,8 & 169 & 93,4 & \\
\hline \multicolumn{8}{|l|}{ Transportasi } \\
\hline Jalan Kaki & 0 & 0 & 1 & 0,6 & 1 & 0,6 & \multirow[t]{3}{*}{0,738} \\
\hline Angkot & 1 & 0,6 & 8 & 4,4 & 9 & 5 & \\
\hline Motor/Mobil Pribadi & 33 & 18,2 & 138 & 76,2 & 171 & 94,5 & \\
\hline \multicolumn{8}{|l|}{ Status Gizi } \\
\hline Lila $<23,5 \mathrm{~cm}$ & 3 & 1,7 & 26 & 14,4 & 29 & 16 & \multirow[t]{3}{*}{0,446} \\
\hline Lila $23,5 \mathrm{~cm}$ & 1 & 0,6 & 4 & 2,2 & 5 & 2,8 & \\
\hline Lila $>23,5 \mathrm{~cm}$ & 30 & 16,6 & 117 & 64,6 & 147 & 81,2 & \\
\hline \multicolumn{8}{|l|}{ Kenaikan Berat Badan } \\
\hline$<11,5 \mathrm{~kg}$ & 21 & 11,6 & 126 & 69,6 & 147 & 81,2 & \multirow[t]{3}{*}{0,005} \\
\hline $11,5-16 \mathrm{~kg}$ & 9 & 5 & 14 & 7,7 & 23 & 12,7 & \\
\hline$>16 \mathrm{~kg}$ & 4 & 2,2 & 7 & 3,9 & 11 & 6,1 & \\
\hline \multicolumn{8}{|l|}{ Pemeriksaan ANC } \\
\hline $1-3 x$ & 3 & 1,7 & 21 & 11,6 & 24 & 13,3 & \multirow[t]{3}{*}{0,656} \\
\hline $4 x$ & 3 & 1,7 & 15 & 8,3 & 18 & 9,9 & \\
\hline$>4 x$ & 28 & 15,5 & 111 & 61,3 & 139 & 76,8 & \\
\hline \multicolumn{8}{|l|}{ Kepemilikan Buku KIA } \\
\hline Tidak ada & 0 & 0 & 2 & 1,1 & 2 & 1,1 & \multirow[t]{2}{*}{0,494} \\
\hline Ada, Dibaca & 34 & 18,8 & 145 & 80,1 & 179 & 98,9 & \\
\hline \multicolumn{8}{|l|}{ Pendidikan } \\
\hline SD/SMP & 18 & 9,9 & 84 & 46,4 & 102 & 56,4 & \multirow[t]{3}{*}{0,209} \\
\hline SMA & 15 & 8,3 & 47 & 26 & 62 & 34,3 & \\
\hline $\mathrm{PT}$ & 1 & 0,6 & 16 & 8,8 & 17 & 9,4 & \\
\hline
\end{tabular}




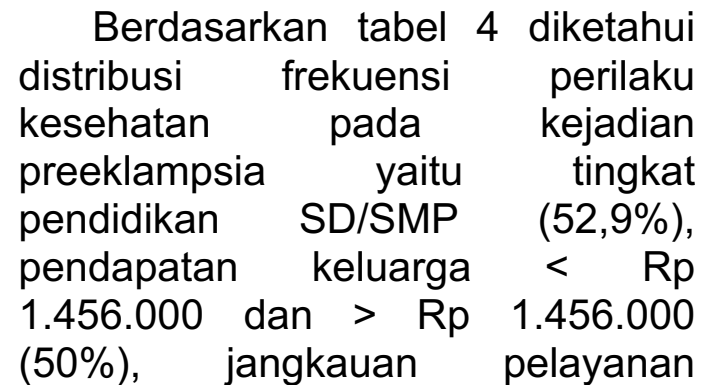
kesehatan dengan jarak tempuh $>2$ $\mathrm{km} \quad(88,2 \%)$, kendaraan yang digunakan menuju tempat pemeriksaan kehamilan dengan motor/mobil pribadi $(97,1 \%)$, status gizi ibu dengan kondisi lila $>23,5 \mathrm{~cm}$ $(88,2 \%)$, kenaikan berat badan < $11,5 \mathrm{~kg}(81,8 \%)$, jumlah kunjungan pemeriksaan ANC > 4x $(82,4 \%)$ dan memiliki buku KIA yang pernah dibaca untuk mengetahui isi dan kegunaan buku tersebut (100\%).

Responden yang tidak mengalami preeklampsia sebagian besar memiliki tingkat pendidikan SD/SMP $(57,1 \%)$, pendapatan keluarga > Rp 1.456.000 (59,2\%), jangkauan pelayanan kesehatan dengan jarak tempuh > $2 \mathrm{~km}$ (94,6\%), kendaraan yang digunakan menuju tempat pemeriksaan kehamilan dengan motor/mobil pribadi $(93,9 \%)$, status gizi ibu dengan kondisi lila $>23,5 \mathrm{~cm}$ $(79,6 \%)$, kenaikan berat badan < $11,5 \mathrm{~kg}(85,7 \%)$, jumlah kunjungan pemeriksaan ANC > 4x $(75,5 \%)$ dan memiliki buku KIA yang pernah dibaca untuk mengetahui isi dan kegunaan buku tersebut (100\%).

Hasil penelitian pada tabel 4 menunjukkan hubungan yang signifikan antara kenaikan berat badan dengan kejadian preeklampsia $(P=0,005)$ sedangkan tingkat pendidikan, pendapatan keluarga, jangkauan pelayanan, transportasi, status gizi, pemeriksaan ANC, kepemilikan buku KIA terdapat hubungan yang tidak signifikan terhadap kejadian preeklampsia.

Berdasarkan tabel 5 diketahui distribusi frekuensi faktor resiko kejadian preeklampsia yaitu berusia 20-34 tahun (55,9\%), paritas sebanyak $2-4 \mathrm{x}(58,8 \%)$, tidak ada dalam keluarga yang memiliki riwayat preeklampsia $(77,5 \%)$, obesitas termasuk dalam kategori gemuk $(55,9 \%)$, kehamilan tunggal $(99,4 \%)$, interval kehamilan $\leq 5$ $(55,9 \%)$, tidak ada yang menderita diabetes gestasional (100\%) dan tidak ada yang memiliki riwayat medis atau penyakit yang diderita sebelum hamil $(67,6 \%)$.

Responden yang tidak mengalami preeklampsia sebagian besar berusia $20-34$ tahun $(59,9 \%)$, paritas sebanyak $2-4 \times(65,3 \%)$, tidak ada dalam keluarga yang memiliki riwayat preeklampsia (94,6\%), obesitas termasuk dalam kategori normal $(47,6 \%)$, kehamilan tunggal $(99,3 \%)$, interval kehamilan $\leq 5$ $(53,1 \%)$, tidak ada yang menderita diabetes gestasional (100\%) dan tidak ada yang memiliki riwayat medis atau penyakit yang diderita sebelum hamil $(84,4 \%)$.

Hasil penelitian pada tabel 5 menunjukkan terdapat hubungan yang signifikan antara riwayat medis dengan kejadian preeklampsia $(P=0,022)$ sedangkan usia ibu, paritas, riwayat keluarga preeklampsia, obesitas, kehamilan kembar, interval kehamilan dan diabetes gestasional terdapat hubungan yang tidak signifikan terhadap kejadian preeklampsia. 
Tabel 5. Faktor-Faktor Resiko Kejadian Preeklampsia Pada Ibu Hamil di Poliklinik Obstetri Gynekologi RSUD Kabupaten Kediri Bulan Juni-Agustus 2017

\begin{tabular}{|c|c|c|c|c|c|c|c|}
\hline \multirow{3}{*}{ Variabel } & \multicolumn{6}{|c|}{ Preeklampsia } & \multirow{3}{*}{$\boldsymbol{P}$} \\
\hline & \multicolumn{2}{|c|}{$\mathrm{Ya}$} & \multicolumn{2}{|c|}{ Tidak } & \multicolumn{2}{|c|}{ Total } & \\
\hline & $\mathbf{n}$ & $\%$ & $\mathbf{N}$ & $\%$ & $\mathbf{n}$ & $\%$ & \\
\hline \multicolumn{8}{|l|}{ Usia Ibu } \\
\hline$<20$ tahun & 2 & 1,1 & 10 & 5,5 & 12 & 6,6 & 0,859 \\
\hline 20-34 tahun & 19 & 10,5 & 88 & 48,6 & 107 & 59,1 & \\
\hline$\geq 35$ tahun & 13 & 7,2 & 49 & 27,1 & 62 & 34,3 & \\
\hline \multicolumn{8}{|l|}{ Paritas } \\
\hline $1 \mathrm{x}$ & 12 & 6,6 & 44 & 24,3 & 56 & 30,9 & 0,776 \\
\hline $2-4 x$ & 20 & 11 & 96 & 53 & 116 & 64,1 & \\
\hline$>4 x$ & 2 & 1.1 & 7 & 3,9 & 9 & 5 & \\
\hline \multicolumn{8}{|c|}{ Riwayat Keluarga Preeklampsia } \\
\hline Tidak ada & 31 & 17,1 & 139 & 76,8 & 170 & 93,9 & 0,457 \\
\hline Ada & 3 & 1,7 & 8 & 4,4 & 11 & 6,1 & \\
\hline \multicolumn{8}{|l|}{ Obesitas } \\
\hline Kurus & 2 & 1,1 & 18 & 9,9 & 20 & 11 & 0,209 \\
\hline Normal & 13 & 7,2 & 70 & 38,7 & 83 & 45,9 & \\
\hline Gemuk & 19 & 10,5 & 59 & 32,6 & 78 & 43,1 & \\
\hline \multicolumn{8}{|l|}{ Kehamilan Kembar } \\
\hline Tunggal & 34 & 18,8 & 146 & 80,7 & 180 & 99,4 & 0,630 \\
\hline Ganda & 0 & 0 & 1 & 0,6 & 1 & 0,6 & \\
\hline \multicolumn{8}{|l|}{ Interval Kehamilan } \\
\hline$\leq 5$ tahun & 19 & 10,5 & 78 & 43,1 & 97 & 53,6 & 0,766 \\
\hline$>5$ tahun & 15 & 8,3 & 69 & 38,1 & 84 & 46,4 & \\
\hline \multicolumn{8}{|l|}{ Diabetes Gestasional } \\
\hline Tidak ada & 34 & 18,8 & 147 & 81,2 & 181 & 100 & 181 \\
\hline \multicolumn{8}{|l|}{ Riwayat Medis } \\
\hline Tidak Ada & 23 & 12,7 & 124 & 68,5 & 147 & 81,2 & 0,022 \\
\hline Diabetes Melitus & 2 & 1,1 & 1 & 0,6 & 3 & 1,7 & \\
\hline Hipertensi & 9 & 5 & 22 & 12,2 & 31 & 17,1 & \\
\hline
\end{tabular}

Tabel 6. Variabel Dominan yang Berhubungan dengan Kejadian Preeklampsia Pada Ibu Hamil di Poliklinik Obstetri Gynekologi RSUD Kabupaten Kediri Bulan JuniAgustus 2017

\begin{tabular}{llc}
\hline \multicolumn{1}{c}{ Variabel } & $\boldsymbol{P}$ value & $\boldsymbol{R}^{2}$ \\
\hline $\begin{array}{l}\text { Kenaikan Berat } \\
\text { Badan }\end{array}$ & 0,007 & 0,180 \\
Riwayat Medis & 0,029 & \\
\hline
\end{tabular}

Tabel 6 kenaikan berat badan merupakan faktor paling dominan yang berhubungan dengan kejadian preeklampsia pada ibu hamil di Poliklinik Obstetri Gynekologi RSUD Kabupaten Kediri dan berperan sebagai prediktor untuk kejadian preeklampsia dengan kuat prediksi sebesar $18 \%\left(R^{2}=0,180\right)$. 
PEMBAHASAN

\section{Analisis Perilaku Kesehatan terhadap Kejadian Preeklampsia}

Hasil penelitian terhadap variabel perilaku kesehatan, menunjukkan bahwa terdapat hubungan yang signifikan antara kenaikan berat badan dengan kejadian preeklampsia dan kenaikan berat badan merupakan faktor paling dominan yang berhubungan dengan kejadian preeklampsia. Beberapa penelitian menunjukkan bahwa kenaikan berat badan ibu yang berlebihan dikaitkan dengan risiko preeklampsia, meskipun ini mungkin dikacaukan oleh peningkatan retensi cairan pada preeklamsia yang berkontribusi terhadap berat badan yang lebih tinggi ${ }^{11}$. Wanita dengan kenaikan berat badan gestasional yang berlebihan memiliki peningkatan risiko gangguan hipertensif kehamilan sebesar 3 kali lipat $(95 \% \mathrm{Cl}, 1,1-7,2)$ dan risiko preeklampsia 4 kali lipat $(95 \% \mathrm{Cl}$, 1,2-14,5), dibandingkan wanita dengan kenaikan berat badan gestasional normal ${ }^{12}$.

Hasil variabel perilaku kesehatan yang lain, menunjukkan ada hubungan yang tidak signifikan antara tingkat pendidikan, pendapatan keluarga, jangkauan pelayanan, transportasi menuju tempat pemeriksaan kehamilan, status gizi, jumlah pemeriksaan ANC dan kepemilikan buku KIA dengan kejadian preeklampsia. Hal ini diduga karena sebagian besar responden memiliki pendapatan keluarga $>\mathrm{Rp} 1.456 .000$ yang termasuk di atas UMR Kabupaten Kediri, sehingga meskipun jangkauan pelayanan kesehatan dengan jarak tempuh $>2 \mathrm{~km}$ masih dapat ditempuh dengan kendaraan motor/mobil pribadi. Selain itu penghasilan yang di atas UMR akan mempengaruhi perilaku kesehatan ibu dalam hal pemenuhan status gizi ibu yang ditandai dengan kondisi lila $>23,5 \mathrm{~cm}$, jumlah kunjungan pemeriksaan ANC > 4x dan memiliki buku KIA yang pernah dibaca untuk mengetahui isi dan kegunaan buku tersebut meskipun dari tingkat pendidikan sebagian besar responden memiliki pendidikan SD/SMP.

Temuan ini didukung beberapa penelitian sebelumnya mengenai pendidikan sebagai faktor risiko yang tidak signifikan. Pendidikan rendah di sisi lain, mungkin saja secara tidak langsung mewakili status sosial ekonomi rendah dan faktor penentu sosio ekonomi terkait, yang dapat berkontribusi perkembangan preeklampsia. Ketidakpatuhan terhadap perawatan antenatal dapat meningkatkan resiko preeklampsia yang disebabkan karena tingkat pendidikan yang menengah. Kurangnya akses terhadap perawatan, misalnya, dapat menyebabkan manajemen prenatal yang tidak memadai dan pada akhirnya terjadi preeklamsia/eklampsia. Mikronutrien dan kekurangan antioksidan juga berkontribusi terhadap perkembangan preeklampsia ${ }^{3}$.

Sosio-ekonomi juga memegang peranan penting dalam kerentanan perempuan untuk mengalami preeklampsia. Wanita dengan penghasilan lebih rendah memiliki lebih banyak kesulitan dalam akses terhadap perawatan medis, mendapatkan diagnosis sejak dini, skreening deteksi dini dan terapi yang tepat, dan mereka seringkali tidak mendapatkan nutrisi yang sesuai $^{13}$. Hasil ini sejalan dengan penelitian yang dilakukan pada masyarakat Brasil bagian timur laut menunjukkan bahwa lima kluster di Natal dan distrik lain di Brasil yang memiliki kepadatan penduduk tinggi 
serta rendahnya sosial ekonomi memiliki pengaruh terhadap perilaku kesehatan ditandai dengan tingginya angka preeklampsia pada ibu hamil. Ibu hamil yang kurang terlayani dalam hal perawatan kesehatan memiliki frekuensi preeklampsia lebih tinggi yang sering terjadi pada populasi ini ${ }^{14}$.

\section{Analisis Faktor Resiko terhadap Kejadian Preeklampsia}

\section{Riwayat Medis dengan \\ Preeklampsia}

Hasil penelitian menunjukkan bahwa ada hubungan yang bermakna antara riwayat medis ibu hamil dengan kejadian preeklampsia. Hasil penelitian ini sejalan dengan penelitian yang dilakukan di Poliklinik Obs-Gin RSJ Prof. Dr. V. L. Ratumbuysang Kota Manado dengan hasil ada hubungan antara riwayat hipertensi dengan kejadian hipertensi pada ibu hamil $(p=0,002)^{15}$. Hipertensi yang sudah ada sebelumnya, diabetes, dan gangguan vaskular (penyakit ginjal, kondisi autoimun) dikaitkan dengan preeklampsia. Wanita dengan hipertensi kronis memiliki risiko 10$25 \%$ mengalami preeklampsia dibandingkan dengan populasi umum. Risiko ini meningkat menjadi $31 \%$ pada wanita dengan durasi hipertensi yang lebih lama minimal empat tahun atau lebih dengan kondisi hipertensi berat. Diabetes pre-gestasional memiliki resiko $21 \%$ terjadi preeklampsia. Resiko meningkat menjadi 36 sampai $54 \%$ diantara wanita dengan diabetes yang lebih lama terkait dengan penyakit mikrovaskular. Untuk penyakit ginjal ringan (kreatinin serum kurang dari $1.5 \mathrm{mg} / \mathrm{dL}$ ), risiko preeklampsia diperkirakan 20 sampai $25 \%$ tetapi lebih besar dari $50 \%$ untuk wanita hamil dengan penyakit ginjal berat. Preeklampsia juga terjadi lebih sering diantara ibu hamil dengan kondisi autoimun seperti lupus eritematosus sistemik dan sindrom antibodi antifosfolipid ${ }^{11}$.

\section{Usia Ibu dengan Preeklampsia}

Hasil penelitian ini menunjukkan ada hubungan yang tidak signifikan antara usia ibu dengan kejadian preeklampsia. Hasil penelitian ini tidak sejalan dengan penelitian di RSUP DR. M. Djamil Padang menunjukkan bahwa terdapat hubungan yang bermakna antara usia ibu ( $p=0,006, O R=4,886)$ yang berarti ibu hamil yang berumur $<20$ tahun dan $>35$ tahun beresiko 4,886 kali beresiko untuk terkena preeklampsia dibandingkan dengan ibu hamil yang berumur antara 20-35 tahun $^{16}$. Menurut teori yang ada preeklampsia lebih sering didapatkan pada masa awal dan akhir usia reproduktif yaitu usia remaja atau diatas 35 tahun. Ibu hamil $<20$ tahun mudah mengalami kenaikan tekanan darah dan lebih cepat menimbulkan kejang. Sedangkan umur lebih 35 tahun seiring bertambahnya usia rentan untuk terjadinya peningkatan tekanan darah ${ }^{17}$.

Adanya hubungan yang tidak signifikan antara usia ibu dengan kejadian preeklampsia diduga sebagian besar responden berusia 20-35 tahun yang tergolong dalam usia bukan resiko tinggi. Hasil penelitian ini sejalan dengan penelitian yang dilakukan di RS Roemani Muhammadiyah Semarang bahwa tidak ada hubungan yang signifikan faktor umur dengan kejadian preeklampsia $(p=0,768$, $\mathrm{OR}=1,190$ ) artinya ibu hamil umur resiko tinggi mempunyai peluang 1,190 kali mengalami kejadian preeklampsia dibandingkan dengan ibu hamil usia reproduksi ${ }^{27}$. 


\section{Paritas dengan Preeklampsia}

Hasil penelitian ini menunjukkan ada hubungan yang tidak signifikan antara paritas dengan kejadian preeklampsia. Hasil penelitian ini tidak sejalan dengan penelitian di RSU Bahteramas Sulawesi Tenggara menunjukkan bahwa paritas merupakan faktor resiko kejadian preeklampsia dengan OR 2,881 yang berarti ibu hamil dengan paritas $1 \mathrm{x}$ atau primigravida mempunyai resiko mengalami preeklampsia $\quad 2,881 \quad$ kali dibandingkan dengan ibu hamil dengan status paritas multigravida ${ }^{18}$. Resiko preeklampsia pada kehamilan pertama sebesar $4,1 \%$ dibandingkan dengan kehamilan kedua sebesar $1,7 \%$ dan kehamilan ketiga 1,8\%. Hal ini membuktikan bahwa persalinan kedua dan ketiga merupakan persalinan yang aman dari preeklampsia. ${ }^{19}$ Tidak adanya hubungan antara paritas dengan kejadian preeklampsia pada penelitian ini disebabkan sebagian besar responden dengan paritas 2-4 yang tergolong persalinan yang aman dari preeklampsia.

\section{Riwayat Keluarga Preeklampsia dengan Preeklampsia}

Hasil penelitian ini menunjukkan ada hubungan yang tidak signifikan antara riwayat keluarga menderita preeklampsia dengan kejadian preeklampsia. Riwayat keluarga preeklampsia berkontribusi terjadinya preeklampsia (OR 2,3-2,6) artinya riwayat keluarga preeklampsia mempunyai resiko mengalami preeklampsia 2,3-2,6 kali dibandingkan dengan ibu hamil yang tidak memiliki riwayat keluarga dengan preeklampsia ${ }^{20}$. Preeklampsia memiliki komponen genetik yang jelas. Dalam sebuah studi antargenerasi tentang kontribusi ayah dan ibu terhadap preeklampsia, wanita yang ibunya memiliki preeklampsia lebih mungkin untuk mengalami preeklampsia pada kehamilannya. Pria yang dilahirkan karena preeklampsia cenderung menjadi ayah dengan preeklampsia. Baik wanita maupun pria, yang memiliki riwayat keluarga dengan preeklamsia dikaitkan dengan preeklampsia yang lebih parah pada indeks kehamilan $^{21}$. Hasil pemindaian genom keluarga Icelandic, yang mencakup 124 silsilah dari 343 wanita yang terkena dampak preeklamsia, diterbitkan oleh Arngr'ımsson et al mengungkapkan lokus kerentanan ibu untuk preeklampsia terdapat pada kromosom 2p13. Hubungan genetik dengan kromosom $2 q, 5 q$, dan $13 q$ ditunjukkan di kelompok preeklampsia Australian ${ }^{22}$. Adanya hubungan yang tidak signifikan antara riwayat keluarga preeklampsia dengan kejadian preeklampsia pada hasil penelitian ini disebabkan karena sebagian besar responden tidak ada yang memiliki riwayat keluarga dengan preeklampsia. Sehingga tidak memberikan resiko terhadap kejadian preeklampsia.

\section{Obesitas dengan Preeklampsia}

Hasil penelitian ini menunjukkan ada hubungan yang tidak signifikan antara obesitas dengan kejadian preeklampsia. Hasil ini tidak sejalan dengan penelitian yang dilakukan di RSUP DR. M. Djamil Padang menunjukkan bahwa terdapat hubungan yang signifikan antara obesitas dengan kejadian preeklampsia $(p=0,031, O R=4,060)$ yang berarti ibu hamil yang obesitas beresiko 4,060 kali untuk terkena preeklampsia dengan ibu hamil yang tidak mengalami obesitas ${ }^{16}$. Obesitas adalah faktor risiko untuk preeklampsia, kondisi ini mungkin 
terkait dengan adanya stres oksidatif, peradangan dan fungsi vaskular yang berubah. Infiltrasi vaskular neutrofil dan peradangan vaskular yang ekstensif telah dilaporkan pada ibu hamil preeklampsia dan wanita gemuk ${ }^{23}$. Kegemukan dikaitkan dengan peradangan tingkat rendah dan peningkatan sirkulasi inflamasi. Kadar protein C-reaktif plasma, TNFa, IL-6 dan IL-8 meningkat pada subyek obesitas, dan lemak tubuh adalah sumber yang mungkin dari penanda inflamasi ini. Penanda peradangan adalah meningkatnya pembuluh darah wanita gemuk dan ini dapat menyebabkan target vaskuler dalam perubahan vaskular yang berhubungan dengan preeklampsia. Obesitas juga terkait dengan peningkatan sirkulasi tingkat leptin, dan polimorfisme gen leptin telah dikaitkan dengan peningkatan risiko preeklampsia $^{24}$.

pengembangan

Adanya hasil yang berbeda ini, kemungkinan disebabkan karena sebagian besar responden tergolong dalam kategori tidak obesitas (kurus dan normal). Wanita dengan indeks massa tubuh lebih rendah (IMT) memiliki risiko preeklampsia lebih rendah dibandingkan wanita dengan IMT lebih tinggi ${ }^{25}$. Pada wanita dengan berat badan normal, peningkatan kadar adiponektin dapat menekan ekspresi molekul adhesi pada sel endhotelial vaskular dan sitokin. Produksi dari makrofag untuk meminimalkan proses inflamasi yang terkait dengan kejadian preeklampsia $^{24}$. Hal ini sejalan dengan penelitian yang dilakukan di RSH Makassar yang menunjukkan bahwa obesitas bukan merupakan faktor resiko dari kejadian preeklampsia $\quad(p=0,417$, $\mathrm{OR}=2,375)^{26}$.

\section{Kehamilan Kembar dengan Preeklampsia}

Hasil penelitian ini menunjukkan ada hubungan yang tidak signifikan antara kehamilan kembar dengan kejadian preeklampsia. $\mathrm{Hal}$ ini disebabkan sebagian besar responden dengan kondisi kehamilan tunggal. Hasil ini sejalan dengan penelitian yang dilakukan di RS Roemani Muhammadiyah Semarang bahwa tidak ada hubungan yang signifikan kehamilan ganda dengan kejadian preeklampsia $(p=1)^{27}$. Kehamilan ganda merupakan faktor resiko terjadinya preeklampsia (OR 3,5) artinya kehamilan ganda mempunyai resiko mengalami preeklampsia 3,5 kali dibandingkan dengan ibu hamil dengan kehamilan tunggal ${ }^{20}$.

\section{Interval Kehamilan dengan Preeklampsia}

Hasil penelitian ini menunjukkan ada hubungan yang tidak signifikan antara interval kehamilan dengan kejadian preeklampsia. Adanya hubungan yang tidak signifikan antara interval kehamilan dengan kejadian preeklampsia disebabkan karena sebagian besar responden memiliki jarak kehamilan $<5$ tahun. Hasil meta analisis semua penelitian dari data kohort retrospektif di negara berpenghasilan tinggi ditemukan bahwa hanya dua dari empat dataset yang bisa dianalisis secara meta bahwa saat membandingkan interval antar kehamilan dibawah 2 tahun dengan interval 2-4 tahun, tidak ada peningkatan risiko yang signifikan aOR=1,01 (95\% Cl 0,95-1.07). Di sisi lain, saat membandingkan interval lebih dari 4 tahun dengan interval 24 tahun, ditemukan kenaikan kecil yang signifikan, aOR $=1,10(95 \% \mathrm{Cl}$ 1,02-1,19]. Sehingga disimpulkan tidak adanya heterogenitas interval 
persalinan dengan kejadian preeklampsia $^{28}$. Jarak kehamilan $>2$ tahun merupakan rekomendasi yang tepat bagi wanita untuk hamil lagi. Interval antar kehamilan pendek ( $<18$ bulan) berhubungan dengan hasil kehamilan yang merugikan karena penipisan nutrisi ibu dan kegagalan untuk mengobati morbiditas. Sedangkan interval antar-kehamilan yang terlalu lama memungkinkan pemulihan alatalat reproduksi ibu secara sempurna tetapi hal ini terkait dengan berkurangnya kesuburan, usia tua, gangguan maternal dan perubahan pasangan yang juga terkait dengan risiko pre-eklampsia yang lebih tinggi. Analisis terbaru dari 894.476 wanita dengan kehamilan berturutturut dalam 18 negara di Amerika Latin menunjukkan bahwa interval kelahiran yang lebih lama meningkatkan kemungkinan preeklampsia $^{29}$.

\section{Diabetes Gestasional dengan Preeklampsia}

Hasil penelitian ini menunjukkan ada hubungan yang tidak signifikan antara diabetes gestasional dengan kejadian preeklampsia. Hal ini disebabkan karena $100 \%$ responden tidak mengalami diabetes gestasional sehingga tidak memiliki pengaruh terhadap kejadian preeklampsia pada ibu hamil. Selama kehamilan normal, wanita mengalami resistansi insulin singkat dan glikemia setelah makan. Peningkatan konsumsi gula pada wanita hamil dapat menyebabkan hiperglikemia, yang pada gilirannya menghambat vasorelaksinasi endotelium. Diabetes gestational terkait dengan IMT tinggi dan peningkatan risiko preeklampsia ${ }^{24}$. Terjadinya peningkatan resistensi insulin atau pembengkakan telah dikaitkan dengan disfungsi endothelial, dan peningkatan sekresi endotelin 1 (vasokonstriktor kuat). Resistensi insulin dapat mengurangi oksida nitrat, meningkatkan risikonya hipertensi dan penyakit kardiovaskular $^{23}$.

\section{KESIMPULAN}

Perilaku kesehatan dan faktor resiko yang mempengaruhi terhadap kejadian preeklampsia pada ibu hamil yaitu kenaikan berat badan ibu selama hamil $(p=0,005)$ dan riwayat medis yang diderita oleh ibu sebelum hamil $(p=0,022)$. Hasil analisis multivariat menunjukkan faktor paling dominan terhadap kejadian preeklampsia adalah kenaikan berat badan $(p=0,007)$. Kenaikan berat badan $(p=0,007)$ dan riwayat medis $(p=0,029)$ mempunyai hubungan yang bermakna dengan kejadian preeklampsia pada ibu hamil dan berperan sebagai prediktor untuk kejadian preeklampsia dengan kuat prediksi sebesar $18 \%\left(R^{2}=0,180\right)$. Pendidikan, pendapatan keluarga, jangkauan pelayanan, transportasi, status gizi, pemeriksaan ANC, kepemilikan buku KIA, pendidikan, usia ibu, paritas, riwayat keluarga preeklampsia, obesitas, kehamilan kembar, interval kehamilan dan diabetes gestasional terdapat hubungan yang tidak signifikan.

Untuk membantu mengenali dan mencegah resiko terjadinya preeklampsia, petugas kesehatan dapat meningkatkan kualitas pemeriksaan ANC dengan cara melakukan skreening deteksi dini preeklampsia dengan memperhatikan perilaku kesehatan yaitu kenaikan berat badan pada ibu hamil dan faktor resiko kejadian preeklampsia yaitu riwayat medis yang diderita ibu sebelum hamil. Serta memberikan penyuluhan dan sosialisasi mengenai idealnya 
kenaikan berat badan selama hamil dan penyakit yang diderita ibu sebelum hamil (riwayat medis) yang beresiko terjadinya preeklampsia pada kehamilan. Untuk peneliti selanjutnya disarankan melakukan penelitian dengan menggunakan skreening deteksi dini preeklampsia dengan menggunakan metode yang berbeda, tidak berdasarkan pada perilaku kesehatan dan faktor resiko kejadian preeklampsia.

\section{UCAPAN TERIMAKASIH}

Penelitian ini dibiayai oleh Direktorat Riset dan Pengabdian Masyarakat Direktorat Jenderal Penguatan Riset dan Pengembangan Kementerian Riset, Teknologi, dan Pendidikan Tinggi sesuai dengan Surat Perjanjian Penugasan Pelaksanaan Program Penelitian 067/ SP2H/ PPM/ K7/ KM/ 2017 Tanggal 10 Maret 2017.

\section{DAFTAR PUSTAKA}

1. Ririn H. SRHR dan Agenda 2030. Indonesia: Rutgers WPF; 2015.

2. Dinkes Propinsi. Tentang AKI dan AKB. Jawa Timur; 2015.

3. Fortner RT, Pekow P, Solomon CG, Markenson G, ChasanTaber L. Prepregnancy Body Mass Index, Gestational Weight Gain, and Risk of Hypertensive Pregnancy among Latina Women. Am J Obstet Gynecol. Feb; 2009 200(2):167 e161-167. [PubMed: 19070831].

4. Dinkes Kabupaten. Profil Kesehatan Ibu dan Anak Tahun 2016. Kediri; 2017.

5. RSUD Kabupaten Kediri. Rekam Medik Kejadian Preeklampsia Pada Ibu Hamil. Kediri; 2016.

6. Lin, Saunders et al. Preeclampsia has an Adverse Impact on Maternal and Fetal Death. Elsevier Inc. 2015.
7. Saadat M, Nejad SM, Habibi G, Sheikhvatan M. Maternal and Neonatal Outcomes in Women with Preeclampsia. Taiwan J Obstet Gynecol: Vol 46, No 3. 2007.

8. Gruslin A, Lemyre B. Preeclampsia: Fetal Assesment and Neonatal Outcomes. Best Practice \& Research Clinical Obstetrics and Gynaecology. 2011; 25: 491-507 Elsevier Inc.

9. North RA, McCowan LME, Dekker GA, Poston L, Chan EHY, Stewart A W; Black M A, Taylor RS, Walker JJ, Baker PN, Kenny LC. Clinical Risk Prediction for Pre-eclampsia in Nulliparous Women: Development of Model in International Prospective Cohort. 2011. Pubmed.

10. Kementerian Kesehatan RI. Rencana Strategis Kementerian Kesehatan Tahun 2010-2014. Jakarta; 2010.

11. Jeyabalan, Arun. Epidemiology of Preeclampsia: Impact of Obesity. Nutr Rev. Author manuscript; available in PMC 2014 October 01.

12. Bilano VL, Ota E, Ganchimeg T, Mori R, Souza JP. Risk Factors of Pre-eclampsia/Eclampsia and Its Adverse Outcomes in Low and Middle Income Countries: A WHO Secondary Analysis. PLOS ONE.www.plosone.org. March 2014. Volume 9.Issue 3. E91198.

13. Delahaije DHJ, van Kuijk SMJ, Dirksen CD, Sep SJS, Peeters LL, Spaanderman ME, Bruinse HW, Zuurendonk LD, van der Pos JAM, Duvekot JJ, van Eyck $J$, van Pampus MG, van der Hoeven MABHM, Smits LJ. Cost-Effectiveness of Reccurence Risk Guided Care Versus Care as Usual in Women 
Who Suffered from Early-Onset Preeclampsia including HELLP Syndrome in Their Previous Pregnancy (the PreCare Study). BMC Pregnancy and Childbirth 2010, 10:60, http://www.biomedcentral.com/1 471-2393/10/60.

14. Dantas, Edailna Maria de Melo; Pereira, F V Marinho; Queiroz, J Wilton; Dantas, Diogo Luis de Melo; Monteiro, G R Gois; Duggal, Priya; Azevedo, Maria de Fatima; Jeronimo, S M Bezerra; Araujo, A C P Fernandes. 2013. Preeclampsia is Associated with Increased Maternal Body Weight in a Northeastern Brazilia Population. BMC Pregnancy and Childbirth 2013, 13:159, http://www.biomedcentral.com/1 471-2393/13/159.

15. Radjamuda, Nelawati dan Montolalu, Agnes. Faktor-Faktor Resiko yang Berhubungan dengan Kejadian Hipertensi pada Ibu Hamil di Poli Klinik ObsGin RSJ Prof. Dr. V. L. Ratumbuysang Kota Manado. Jurnal IImiah Bidan ISSN: 23391731 Volume 2 Nomor 1 JanuariJuni 2014.

16. Nursal, Dien Gusta Anggraini; Tamela, Pratiwi; Fitrayeni. Faktor Resiko Kejadian Preeklampsia pada Ibu Hamil di RSUP DR. M. Djamil Padang Tahun 2014. Jurnal Kesehatan Masyarakat Andalas, p-ISSN 1978-3833, e-ISSN 2442-6725. 10(1)38-44@ @ 2016 JKMA. http://jurnal.fkm.unand.ac.id/ind ex.php/jkma/

17. Djannah, S. Gambaran Epidemiologi Kejadian Preeklampsia/Eklampsia di RSU PKU Muhammadiyah Yogyakarta Tahun 2007-2009.
Yogyakarta:Universitas Ahmad Dahlan; 2010.

18. Afridasari, Sitti Nur; Saimin, Juminten; Sulastrianah. Analisis Faktor Resiko Kejadian Preeklampsia. FK UHO; 2013.

19.Diaz, Sonia H; Toh, Sengwee; Cnattingius, Sven. Risk of Preeclampsia in First and Subsequent Pregnancies: Prospective Cohort Study. BMJ 2009:338:b2255.doi:10.1136/bm j.b2255.

20. Uzan, Jennifer; Carbonnel; Marie; Piconne, Olivier; Asmar, Roland; Ayoubi, Jean-Marc. Preeclampsia: Pathophysiology, Diagnosis, and Management. Vascular Health and Risk Management 2011:7 467-474.

21. Bushnell, Cheryl and Chireau, Monique. Review Article: Preeclampsia and Stroke Risks During and After Pregnancy. SAGE-Hindawi Acces to Research Stroke Research and Treatment Volume 2011, Article ID $858134, \quad 9$ pages doi:10.4061/2011/858134.

22. Haram, Kjell; Mortensen, Jan Helge; Nagy, B. Review Article: Genetic Aspects of Preeclampsia and the HELPP Syndrome. Hindawi Publishing Corporation Journal of Pregnancy Volume 2014, Article ID 910751, 13 pages http://dx.doi.org/10.1155/2014/9 10751.

23. Walsh, SW. Obesity: a Risk Factor for Preeclampsia. Trends Endocrinol Metab 2007, 18:365370.

24. Reslan, Ossama M and A. Khalil, Raouf. Molecular and Vascular Targets in the Pathogenesis and Management of the Hypertension Associated with Preeclampsia. Cardiovasc 
Hematol Agents Med Chem. 2010 October 1; 8(4):204-226.

25. Belogolovkin, V; Eddleman, KA; Malone, FD; Sullivan, L; Ball, $\mathrm{RH}$; Nyberg, DA. The Effect of Low Body Mass Index on the Development of Gestational Hypertension and Preeclampsia. J Matern Fetal Neonatal Med 2007, 20:509-513.

26. Langelo, Wahyuny; Arsin, A.Arsunan; Russeng, Syamsiar. Faktor Resiko Kejadian Preeklampsia di RSKD Ibu dan Anak Siti Fatimah Makassar Tahun 2011-2012. Makassar: FKM Universitas Hasanuddin; 2012.

27. Sutrimah; Mifbakhuddin; Wahyuni, Dwi. Faktor-Faktor yang Berhubungan dengan Kejadian Preeklampsia pada Ibu Hamil di RS Roemani Muhammadiyah Semarang. Semarang: Universitas Muhammadiyah; 2014.

28. Cormick, Gabriela; Betran, Ana Pilar; Ciapponi, Agustin; Hall, David R; Hofmeyr, G.Justus. Inter-pregnancy Interval and Risk of Reccurent Preeclampsia: Systematic Review and Metaanalysis. Reproductive Health (2016) 13:83 DOI 10.1186/s12978-016-0197-x.

29. Mignini, LE; Carroli, G; Betrán, AP; Fescina, R; Cuesta, C; Campodinico, L; De Muncio B, Khan KS. Interpregnancy Interval and Maternal and Perinatal Outcome in 894,476 Women: A Multicountry Study. BJOG. 2015 Sep 24.doi: 10.1111/1471 0528.13625. 